\title{
Increasing biomass carbon stocks in trees outside forests in China over the last three decades
}

\author{
Z. D. Guo ${ }^{1,3}$, H. F. Hu ${ }^{2}$, Y. D. Pan ${ }^{4}$, R. A. Birdsey ${ }^{4}$, and J. Y. Fang ${ }^{1,2}$ \\ ${ }^{1}$ Department of Ecology, College of Urban and Environmental Science, and Key Laboratory for Earth Surface Processes of \\ the Ministry of Education, Peking University, Beijing 100871, China \\ ${ }^{2}$ State Key Laboratory of Vegetation and Environmental Change, Institute of Botany, Chinese Academy of Sciences, \\ Beijing 100093, China \\ ${ }^{3}$ National Satellite Meteorological Center, China Meteorological Administration, Beijing 100081, China \\ ${ }^{4}$ USDA Forest Service, Northern Research Station, Newtown Square, PA 19073, USA
}

Correspondence to: J. Y. Fang (jyfang@urban.pku.edu.cn)

Received: 23 January 2014 - Published in Biogeosciences Discuss.: 7 March 2014

Revised: 26 June 2014 - Accepted: 27 June 2014 - Published: 5 August 2014

\begin{abstract}
Trees outside forests (TOF) play important roles in national economies, ecosystem services, and international efforts for mitigating climate warming. Detailed assessment of the dynamics of carbon (C) stocks in China's TOF is necessary for fully evaluating the role of the country's trees in the national $\mathrm{C}$ cycle. This study is the first to explore the changes in biomass $\mathrm{C}$ stocks of China's TOF over the last three decades, using the national forest inventory data in six periods from 1977 to 2008. According to the definition of the forest inventory, China's TOF could be categorized into three groups: woodlands, shrubberies, and trees on non-forest land (including four-side greening trees, defined in the article, and scattered trees). We estimated biomass $\mathrm{C}$ stocks of woodlands and trees on non-forest land by using the provincial biomass-volume conversion equations derived from the data of low-canopy forests, and estimated the biomass $\mathrm{C}$ stocks of shrubberies using the provincial mean biomass density. Total TOF biomass $\mathrm{C}$ stock increased by $62.7 \%$ from $823 \mathrm{Tg} \mathrm{C}\left(1 \mathrm{Tg}=10^{12} \mathrm{~g}\right)$ in the initial period of 1977-1981 to $1339 \mathrm{Tg} \mathrm{C}$ in the last period of 2004-2008. As a result, China's TOF have accumulated biomass $\mathrm{C}$ of $516 \mathrm{Tg}$ during the study period, with 12,270 , and $234 \mathrm{Tg}$ in woodlands, shrubberies, and trees on non-forest land, respectively. The annual biomass $C$ sink of China's TOF averaged $19.1 \mathrm{Tg}$ $\mathrm{C} \mathrm{yr}^{-1}$, offsetting $2.1 \%$ of the contemporary fossil-fuel $\mathrm{CO}_{2}$ emissions in the country. These estimates are equal to $16.5-$ $20.7 \%$ of the contemporary total forest biomass $\mathrm{C}$ stock and $27.2 \%$ of the total forest biomass $\mathrm{C}$ sink in the country, sug-
\end{abstract}

gesting that TOF are substantial components in China's tree C budget.

\section{Introduction}

Contrary to popular perception, trees and forests are not synonymous; trees alone do not make up forests, and trees are not found only in forests (Long and Nair, 1999). Because trees are the largest component of aboveground biomass in terrestrial ecosystems, a number of studies have paid attention to the role of forests in mitigating climate change, carbon (C) sequestration and biodiversity conservation (e.g., IPCC, 2007; Pan et al., 2011; Dolman et al., 2012). In recent decades, trees outside forests (TOF) have begun to attract more and more attention with growing acknowledgements of their potential economic importance and political interest in their environmental services (de Foresta et al., 2013). Because TOF are typically splintered among the categories of agroforestry, urban and rural forestry, and other sectors, they tend to be left out of forest statistics, natural resource assessments, policy, and legislation (de Foresta et al., 2013). A major challenge for a better evaluation of trees and their services globally is to improve our understanding of the status and dynamics of all tree resources, including TOF (FAO, 2001; de Foresta et al., 2013).

The concept of "Trees Outside Forests" first appeared in 1995 to indicate trees growing outside the forest and not 
belonging to forest or other wooded land (Bellefontaine et al., 2002). TOF can be found in all climates, land types, land uses, and regions and have important economic, social, and environmental implications on local, national, and global scales (de Foresta et al., 2013). For instance, in Kerala State, India, TOF are the major source of local wood production, accounting for $90.1 \%$ of the timber production and meeting $89.2 \%$ of local fuelwood supply during the year 2000-2001 (Krishnankutty et al., 2008). Based on biomass equation of species, Nowak and Crane (2002) estimated that urban trees in the USA currently store $700 \mathrm{Tg}\left(1 \mathrm{Tg}=10^{12} \mathrm{~g}\right)$ of carbon (C) with a gross $\mathrm{C}$ sequestration rate of $22.8 \mathrm{Tg} \mathrm{C} \mathrm{yr}^{-1}$. Focusing on trees on land used for agriculture, Zomer et al. (2009) made the first global-scale TOF assessment, and concluded that agroforestry is a significant feature of agriculture in all regions, with $46 \%$ of the total agricultural land (about $1 \times 10^{9}$ ha) having more than $10 \%$ tree cover. In the current context of climate change, biodiversity crisis, financial crises, and food insecurity, the contributions of TOF are significant for improving people's livelihoods and national economies, especially in developing countries (de Foresta et al., 2013). More recently, their importance has gained more attention with an appreciation of the role of TOF in C sequestration, biodiversity conservation, antidesertification, and poverty alleviation (Nair, 2011; de Foresta et al., 2013).

In order to investigate the status and changes of its forest resources, China implemented a national forest resource inventory, compiled every 5 years since the 1970s. Seven categories of forests or trees were periodically surveyed and reported in each inventory period, including the following: (1) forest stands (land spanning more than 0.0667 ha with trees and a canopy cover of $>0.3$ (before 1994 when a different criterion was applied) or $\geq 0.2$ (after 1998)), (2) economic forests (woods with the primary objective of producing fruits, edible oils, drinks, flavorings, industrial raw materials, and medicinal materials), (3) bamboos, (4) woodlands covered by trees with a canopy coverage of between 0.1 and 0.2 or 0.3 (before 1994) (Fig. 1a), (5) shrubberies covered by shrubs with a canopy coverage $>0.3$ or 0.4 (before 1994) (Fig. 1b), (6) four-side greening trees, which, in China, are defined as trees growing and distributed along the sides of the houses, roads, rivers, and cropland (Fig. 1c), and (7) scattered trees, growing alone along with bamboos and in economic forests or non-forest land (Fig. 1d). In China, forest stands, economic forests, and bamboos are usually treated as forests (e.g., Fang et al., 1998, 2001, 2007; Guo et al., 2010, 2013), while the other four categories (woodlands, shrubberies, four-side greening trees, and scattered trees) are regarded as TOF, of which biomass $\mathrm{C}$ stocks and changes over time have rarely been estimated.

Although several previous studies have estimated biomass C stocks for certain types of China's TOF (e.g., Hu et al., 2006; Li et al., 2011; Zhang et al., 2013), they lack comprehensive and systematic analysis on the dynamics of biomass $\mathrm{C}$ stocks and their regional distribution for all components of
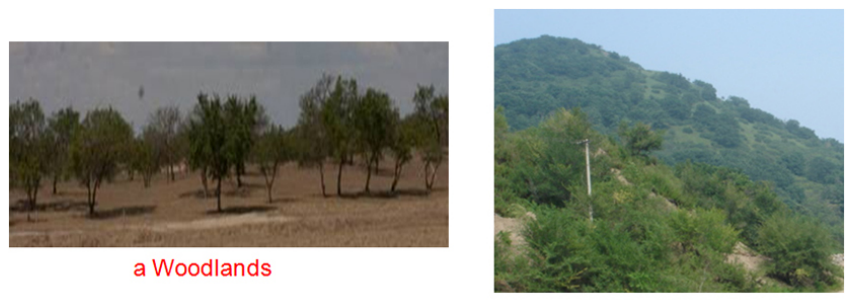

b Shrubberies

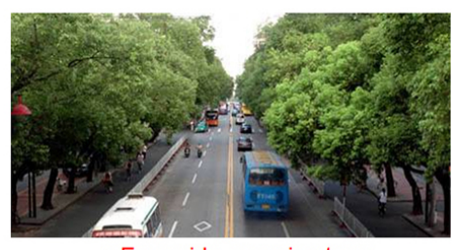

c Four-side greening trees

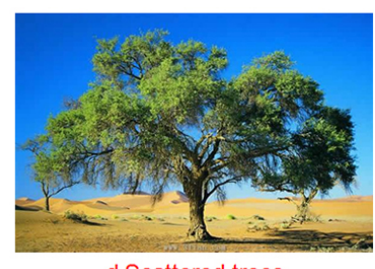

d Scattered trees

Figure 1. Illustrations of four TOF types in China. (a) Woodland, (b) shrubberies, (c) four-side greening trees, and (d) scattered trees.

China's TOF. Based on the up-to-date national forest inventory data starting in the late 1970 s, this study aims to explore the temporal changes and regional distributions of biomass $\mathrm{C}$ stocks for each TOF group and for total TOF between 1977 and 2008.

\section{Data sets and methods}

China's forest inventory data used in this study includes six periods: 1977-1981, 1984-1988, 1989-1993, 1994-1998, 1999-2003, and 2004-2008 (Chinese Ministry of Forestry, 1983, 1989, 1994, 2000, 2005, 2010). The forest inventory provides different information for different TOF categories: it documents total area and total timber volume in each province for woodlands, total area in each province for shrubberies, and total timber volume in each province for four-side greening trees and scattered trees. We estimated their biomass $\mathrm{C}$ stocks for each inventory period based on the available inventory information. Note that TOF in Hong Kong, Macao, and Taiwan were not included in this study due to the lack of data. A ratio of 0.5 was used to convert biomass to $\mathrm{C}$ stock.

\subsection{Woodlands}

Since 1994, the definition of woodlands in China's forest inventory has been changed from a canopy coverage of between 0.1 and 0.3 to a canopy coverage of between 0.1 and 0.2 to be consistent with the FAO (food and agriculture organization of the united nations) criteria. In order to make our results comparable for different inventory periods, we analyzed the 1994-1998 inventory data which provided both criteria $(0.1-0.3$ and $0.1-0.2$ canopy coverage) and found that, at the provincial level, there existed power function relationships for the woodland area and volume between the two 
Table 1. Biomass density of major shrubbery types in China.

\begin{tabular}{|c|c|c|c|}
\hline Shrubbery type & $\begin{array}{r}\text { Biomass } \\
\text { density } \\
\left(\mathrm{Mg} \mathrm{ha}^{-1}\right)\end{array}$ & $\begin{array}{r}\text { Standard } \\
\text { error }\end{array}$ & $\begin{array}{r}\text { Sample } \\
\text { size }\end{array}$ \\
\hline Sclerophyllus evergreen broadleaf scrubs and dwarf forests on seashore in tropical zone & 11.84 & 1.36 & 3 \\
\hline Deciduous scrubs and dwarf forests in temperate and subtropical zones & 21.49 & 5.37 & 8 \\
\hline Subalpine deciduous scrubs in temperate and subtropical zones & 24.02 & 2.71 & 22 \\
\hline Evergreen and deciduous scrubs and dwarf forests on calcareous soil in subtropical and tropical zones & 30.61 & 4.8 & 5 \\
\hline Broadleaf evergreen and deciduous scrubs and dwarf forests on acid soil in subtropical and tropical zones & 20.47 & 1.78 & 7 \\
\hline Alpine and subalpine sclerophylla evergreen scrubs and dwarf forests in subtropical zones & 22.81 & 4.26 & 9 \\
\hline Total & 22.92 & 1.64 & 54 \\
\hline
\end{tabular}
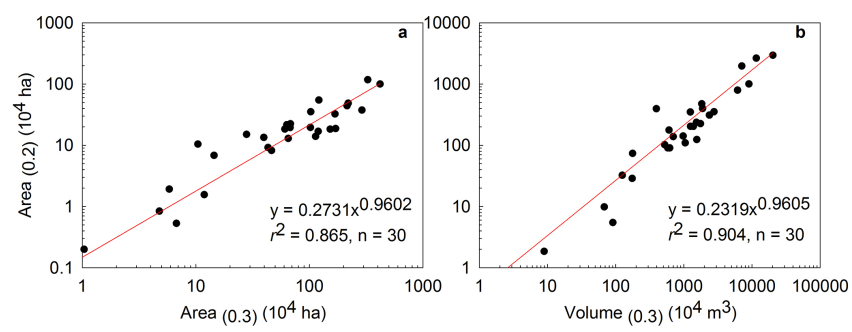

Figure 2. Relationships between the woodland area and volume of the two criteria at the provincial level in 1994-1998: (a) area, (b) volume. The subscripts 0.3 and 0.2 in parentheses represent the criterion of $0.1-0.3$ and $0.1-0.2$ canopy coverage, respectively.

criteria (Fig. 2):

$\operatorname{AREA}_{(0.2)}=0.2731 \times A R E A_{(0.3)}^{0.9602}$

$\left(R^{2}=0.865, n=30\right)$,

$\operatorname{VOLUME}_{(0.2)}=0.2319 \times \operatorname{VOLUME}_{(0.3)}^{0.9605}$

$\left(R^{2}=0.904, n=30\right)$,

where AREA and VOLUME are woodland area $\left(10^{4} \mathrm{ha}\right)$ and volume $\left(10^{4} \mathrm{~m}^{3}\right)$ in a province; subscripts 0.3 and 0.2 represent the criterion of $0.1-0.3$ and $0.1-0.2$ canopy coverage, respectively. Equations (1) and (2) can therefore be used to adjust the area and timber volume of woodlands reported before the inventory period of 1994-1998.

Because forest inventory data only document the total area and volume of woodlands for each province, it is necessary to develop an empirical relationship between the provincial biomass and volume of woodlands. The 1994-1998 inventory data provided the total area and timber volume of forest stands at the criteria of both $>0.3$ and $\geq 0.2$ canopy coverage for each province, and the corresponding biomass at both criteria was hence derived based on biomass expansion factors (BEFs) for 21 forest types in China (for details, see Fang et al., 1998, 2001, 2007, 2014; Guo et al., 2010, 2013), which were almost independent of forest age class and site quality for a forest type (Teobaldelli et al., 2009). Consequently, we could use the differences in biomass, timber volume, and

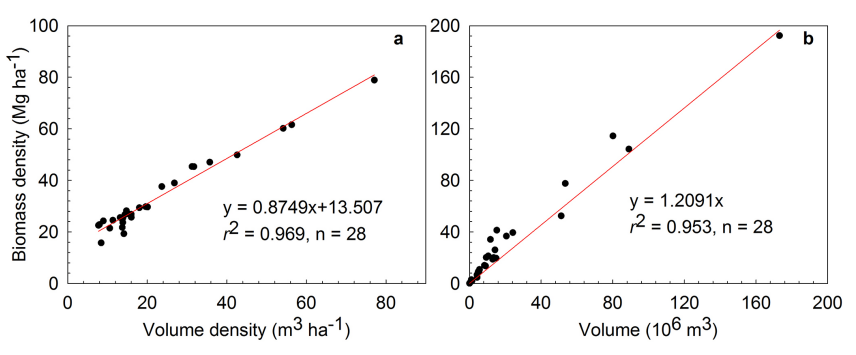

Figure 3. Relationships between biomass density $\left(\mathrm{Mg} \mathrm{ha}^{-1}\right)$ and volume density $\left(\mathrm{m}^{3} \mathrm{ha}^{-1}\right)$ (a) and between biomass $\left(10^{6} \mathrm{Mg}\right)$ and volume $\left(10^{6} \mathrm{~m}^{3}\right)$ (b) for forest stands with a canopy coverage of $0.2-0.3$ at the provincial level in 1994-1998.

area of forest stands in each province between two criteria to obtain the estimates of the provincial biomass density and volume density for forest stands with a canopy coverage of 0.2-0.3 for the 1994-1998 inventory period. Previous studies (Fang and Chen, 2001; Guo et al., 2013) have shown a robust linear relationship between the provincial biomass density and volume density for forest stands at both criteria $(>0.3$ and $\geq 0.2$ canopy coverage). Similarly, we also established a robust linear relationship between biomass density and volume density at the provincial level for forest stands with a canopy coverage of between 0.2 and 0.3 for the 1994-1998 inventory period (Fig. 3a):

$\mathrm{BD}=0.8749 \times \mathrm{VD}+13.507\left(R^{2}=0.969, n=28\right)$,

where $\mathrm{BD}$ and $\mathrm{VD}$ are the biomass density $\left(\mathrm{Mg} \mathrm{ha}^{-1}, 1\right.$ $\left.\mathrm{Mg}=10^{6} \mathrm{~g}\right)$ and volume density $\left(\mathrm{m}^{3} \mathrm{ha}^{-1}\right)$ of forest stands with a canopy coverage of between 0.2 and 0.3 in each province in 1994-1998, respectively.

Equation (3) can be used to estimate biomass density using volume density for relatively sparse canopy forest stands (e.g., woodlands) for each province and each inventory period. We can therefore estimate biomass $\mathrm{C}$ stocks of woodlands by multiplying biomass densities with their corresponding areas. 


\subsection{Shrubberies}

Because forest inventory only documents the area of shrubberies in each province, we established a literature-reviewed database of shrubbery biomass, which contained 54 sets of biomass data for 30 types of shrubbery communities (Supplement Table S1). Using a similar approach to Hu et al. (2006), we updated the mean biomass density of six shrubbery types (Table 1) and recalculated the mean biomass density of shrubberies in each individual province across China (Supplement Table S2). Then, we obtained biomass $\mathrm{C}$ stocks in different inventory periods for China's shrubberies by multiplying the provincial mean biomass density of shrubberies with the area in the corresponding province.

\subsection{Trees on non-forest land}

In this study, we combined four-side greening trees and scattered trees into the same group of trees on non-forest land. Forest inventory only documents the total volume of trees on non-forest land for each province, and so we used the 19941998 inventory data, which provided the total area and timber volume of forest stands at the criteria of both $>0.3$ and $\geq 0.2$ canopy coverage for each province, similar to the analysis for woodlands, to establish a robust linear relationship between total biomass and total volume at the provincial level for coarse-canopy forest stands with a canopy coverage of 0.2-0.3 for the 1994-1998 inventory period (Fig. 3b).

$B=1.2091 \times V\left(R^{2}=0.953, n=28\right)$,

where $B$ and $V$ are the biomass stock $\left(10^{6} \mathrm{Mg}\right)$ and volume $\left(10^{6} \mathrm{~m}^{3}\right)$ of forest stands with a canopy coverage of between 0.2 and 0.3 in each province in 1994-1998, respectively.

Equation (4) can be used to calculate the biomass of trees on non-forest land because four-side greening trees and scattered trees generally grow in sparse, open habitats (Guo, 2011).

\section{Results}

\subsection{Biomass C stocks and C sinks of China's TOF}

Total TOF biomass C stock increased by $62.7 \%$ from $823 \mathrm{Tg}$ $\mathrm{C}$ in the initial period of $1977-1981$ to $1339 \mathrm{Tg} \mathrm{C}$ in the last period of 2004-2008, with a net accumulation of $516 \mathrm{Tg} \mathrm{C}$ (Table 2). Over the $30 \mathrm{yr}$, net $\mathrm{C}$ gain was found between every two sequential inventory periods, and the annual biomass $\mathrm{C}$ sink averaged $19.1 \mathrm{Tg} \mathrm{C} \mathrm{yr}^{-1}$ with a range of $7.7 \mathrm{Tg} \mathrm{C} \mathrm{yr}^{-1}$ in 1999-2003 to $30.9 \mathrm{Tg} \mathrm{C} \mathrm{yr}^{-1}$ in 1989-1993.

Storing $48.6-60.3 \%$ of the total biomass C stock and accounting for $45.3 \%$ of the total biomass $\mathrm{C}$ sink during the study period, trees on non-forest land released $47 \mathrm{Tg}$ $\mathrm{C}$ between 1994 and 2003 and sequestered $281 \mathrm{Tg} \mathrm{C}$ in other periods, resulting in a net accumulation of $234 \mathrm{Tg} \mathrm{C}$ for the whole study period. The mean biomass $\mathrm{C}$ sink was 8.7 $\mathrm{Tg} \mathrm{C} \mathrm{yr}^{-1}$, ranging from $-7.0 \mathrm{Tg} \mathrm{C} \mathrm{yr}^{-1}$ in $1999-2003$ to $27.3 \mathrm{Tg} \mathrm{C} \mathrm{yr}^{-1}$ in $1989-1993$.

Shrubberies stored $33.6-45.2 \%$ of the total biomass C stock and accounted for $52.4 \%(270 \mathrm{Tg} \mathrm{C})$ of the total biomass $\mathrm{C}$ sink over the past three decades, with a persistent $\mathrm{C}$ sink rate of $10.0 \mathrm{Tg} \mathrm{C} \mathrm{yr}^{-1}$ (Table 2). Woodlands stored $6.2-9.0 \%$ of the total biomass $\mathrm{C}$ stock and accounted for $2.4 \%(12 \mathrm{Tg} \mathrm{C})$ of the total biomass $\mathrm{C}$ sink over the study period, with a small overall $\mathrm{C}$ sink rate of $0.5 \mathrm{Tg} \mathrm{C} \mathrm{yr}^{-1}$.

\subsection{Spatiotemporal distribution of the biomass C stocks and C sinks of China's TOF}

There is considerable spatial (or regional) and temporal variability in biomass $\mathrm{C}$ stocks and $\mathrm{C}$ sinks among the entire TOF and each group (Fig. 3; Supplement Table S3). About 34.5$43.3 \%$ of the total TOF biomass $\mathrm{C}$ stock occurred in the southwestern region, followed by $9.8-17.8 \%$ in the northern region, $12.4-15.4 \%$ in the southern region, 9.6-17.4\% in the eastern region, $8.4-15.2 \%$ in the northwestern region, and $8.8-11.5 \%$ in the northeastern region. Over the study period, overall net $\mathrm{C}$ accumulation was found in all regions, except for a release of $14.6 \mathrm{Tg} \mathrm{C}$ in the eastern region, equaling $2.8 \%$ of the total TOF biomass $\mathrm{C}$ sink. The largest TOF biomass $\mathrm{C}$ sink was in the northern region $(158.2 \mathrm{Tg}$ C), accounting for $30.7 \%$ of the total TOF C sink, followed by the northwestern $(134.8 \mathrm{Tg} \mathrm{C}, 26.1 \%)$, the southwestern (105.8 Tg C, $20.5 \%)$, the southern (78.9 Tg C, $15.3 \%)$, and the northeastern region $(52.0 \mathrm{Tg} \mathrm{C}, 10.3 \%)$.

For trees on non-forest land, the largest biomass $\mathrm{C}$ sink occurred in the northern region with an accumulation of $76.0 \mathrm{Tg}$ $\mathrm{C}$ (accounting for $32.5 \%$ of total biomass $\mathrm{C}$ sink in China's trees on non-forest land). The next largest biomass $\mathrm{C}$ sinks were in the northeastern $(64.3 \mathrm{Tg} \mathrm{C}, 27.5 \%)$, southwestern (43.6 Tg C, $18.7 \%$ ), southern (36.5 Tg C, $15.6 \%$ ), and northwestern regions (20.6 Tg C, $8.8 \%$ ). However, trees on nonforest land in the eastern region have functioned as a $\mathrm{C}$ source with a release of $7.3 \mathrm{Tg} \mathrm{C}$ over the past three decades.

For shrubberies, the largest biomass $\mathrm{C}$ sink occurred in the northwestern region with a gain of $100.8 \mathrm{Tg} \mathrm{C}$, accounting for $37.3 \%$ of the total shrubbery biomass $\mathrm{C}$ sink, followed by the northern $(78.4 \mathrm{Tg} \mathrm{C}, 29.0 \%)$, southwestern $(52.4 \mathrm{Tg}$ C, $19.4 \%$ ), and southern regions (44.9 Tg C, 16.6\%). However, shrubberies in the northeastern and eastern regions have acted as $\mathrm{C}$ sources with an accumulated loss of 4.0 and $2.1 \mathrm{Tg} \mathrm{C}$, which equaled 1.5 and $0.8 \%$ of the total shrubbery biomass $\mathrm{C}$ sink in these two regions, respectively.

Woodlands in the northwestern, southwestern, and northern regions have all functioned as $\mathrm{C}$ sinks with an accumulation of 13.4, 9.9, and 3.9 Tg C, respectively, which accounted for $110.0,81.1$, and $31.6 \%$ of the total woodland biomass $\mathrm{C}$ sink. On the other hand, woodlands in the other three regions have all released $\mathrm{C}$ with the largest loss in the northeastern 
Table 2. Biomass C stocks and C sinks in China's TOF during 1977-2008.

\begin{tabular}{|c|c|c|c|c|c|c|c|c|}
\hline \multirow[t]{2}{*}{ Period } & \multicolumn{4}{|c|}{$\mathrm{C}$ stock $(\mathrm{Tg} \mathrm{C}) *$} & \multicolumn{4}{|c|}{$\mathrm{C} \operatorname{sink}\left(\mathrm{Tg} \mathrm{Cyr}^{-1}\right)$} \\
\hline & Total & Woodlands & Shrubberies & $\begin{array}{l}\text { Trees on non- } \\
\text { forest land }\end{array}$ & Total & Woodlands & Shrubberies & $\begin{array}{l}\text { Trees on non- } \\
\text { forest land }\end{array}$ \\
\hline $1977-1981$ & 823 & $70(8.5)$ & $335(40.7)$ & $418(50.7)$ & - & - & - & - \\
\hline 1984-1988 & 960 & $74(7.7)$ & $350(36.5)$ & $535(55.8)$ & 19.6 & 0.5 & 2.2 & 16.8 \\
\hline 1989-1993 & 1114 & $69(6.2)$ & $374(33.6)$ & $672(60.3)$ & 30.9 & -1.1 & 4.7 & 27.3 \\
\hline 1994-1998 & 1195 & $108(9.0)$ & $427(35.7)$ & $660(55.2)$ & 16.1 & 7.9 & 10.6 & -2.4 \\
\hline 1999-2003 & 1233 & $97(7.8)$ & $512(41.5)$ & $625(50.7)$ & 7.7 & -2.3 & 17.0 & -7.0 \\
\hline 2004-2008 & 1339 & $83(6.2)$ & $605(45.2)$ & $651(48.6)$ & 21.1 & -2.8 & 18.7 & 5.3 \\
\hline $1977-2008$ & 516 & $12(2.4)$ & $270(52.4)$ & $234(45.3)$ & 19.1 & 0.5 & 10.0 & 8.7 \\
\hline
\end{tabular}

region (7.3 $\mathrm{Tg} \mathrm{C}, 59.5 \%)$, followed by the eastern (5.2 $\mathrm{Tg} \mathrm{C}$, $42.5 \%)$, and southern regions $(2.5 \mathrm{Tg} \mathrm{C}, 20.6 \%)$.

\section{Discussion}

\subsection{Estimates of biomass $\mathrm{C}$ sink in China's TOF and their implications}

TOF are trees that do not fulfill the criteria for defining a forest, so the extent of their domain depends on the definition used for forest in any country or agency conducting an assessment. Many countries have their own definitions of forest for their forest assessments, which means that many countries have their own criteria regarding what they consider TOF (de Foresta et al., 2013). In this study, we defined China's TOF as comprising woodlands, shrubberies, four-side greening trees, and scattered trees based on the data collection from China's forest inventory. As a result, we estimated that total TOF biomass C stock increased to $1339 \mathrm{Tg}$ $\mathrm{C}$ in the late 2000s (2004-2008) from $823 \mathrm{Tg} \mathrm{C}$ in an initial period of 1977-1981, and the net $\mathrm{C}$ sink was $516 \mathrm{Tg} \mathrm{C}$, of which $12 \mathrm{Tg} \mathrm{C}$ was in woodlands, $270 \mathrm{Tg} \mathrm{C}$ in shrubberies, and $234 \mathrm{Tg} \mathrm{C}$ in trees on non-forest land.

The estimates of biomass $\mathrm{C}$ stocks in woodlands by Pan et al. (2004) for the same inventory periods (1977-1981, 1984-1988, and 1989-1993) are greater than our estimates by $245 \%$ (243 Tg C), $229 \%$ (244 Tg C), and $251 \%$ (241 $\mathrm{Tg}$ C), respectively. These differences are likely to be due to the following reasons. First, different provincial biomassvolume conversion equations that were developed separately were used in the two studies. In their study, Pan et al. (2004) developed the regional biomass-volume equations for woodlands from plot data with a stand growing stock of $<100 \mathrm{~m}^{3}$ $\mathrm{ha}^{-1}$ and a tree density of $<1000$ trees ha ${ }^{-1}$. Second, different criteria for woodlands were used in the two studies. Before 1994, stands with a tree canopy coverage of 10-30\% were defined as woodlands in China's forest resource inventory and this criterion was used in Pan et al. (2004). How- ever, although there are larger differences in the estimated biomass $\mathrm{C}$ stocks in woodlands, both studies show the similar magnitude of biomass $\mathrm{C}$ sink during the period of 19771993: $-2 \mathrm{Tg} \mathrm{C}$ in Pan et al. (2004) and $-1.7 \mathrm{Tg} \mathrm{C}$ in our study. These estimates are different in recent work by Zhang et al. (2013), who estimated that China's woodlands had released a biomass $\mathrm{C}$ of $0.12 \mathrm{Pg}\left(1 \mathrm{Pg}=10^{15} \mathrm{~g}\right)$ over the last three decades (1977-2008). This may be because Zhang et al. (2013) overestimated biomass C stocks in woodlands for the inventory periods of 1977-1981, 1984-1988, and 19891993 by using the previous criterion for woodlands. In addition, they used a constant mean biomass density $(19.76 \mathrm{Mg}$ $\mathrm{ha}^{-1}$ ) to estimate the biomass $\mathrm{C}$ stocks of woodlands from 1977-2008, which may be a factor causing a C release.

We summarized total biomass $\mathrm{C}$ stocks and $\mathrm{C}$ sinks of China's forests and TOF during 1977-2008 in Table 3. Compared with forests, the total TOF biomass C stock was $16.5 \%$ (1977-1981)-20.7\% (1994-1998) of the contemporary total biomass $\mathrm{C}$ stock of forests; and the total TOF biomass $\mathrm{C}$ sink was $27.2 \%$ of the total biomass $\mathrm{C}$ sink of forests, with a large fluctuation from $7.5 \%$ in $1999-2003$ to $160.3 \%$ in 1994-1998.

We used the $\mathrm{C}$ estimates of China's TOF to assess their relative roles in offsetting fossil-fuel $\mathrm{CO}_{2}$ emissions. Similar to Guo et al. (2013), we estimated China's fossil-fuel $\mathrm{CO}_{2}$ emissions as $27.7 \mathrm{Pg} \mathrm{C}$ during 1977-2008, at an average rate of $895 \mathrm{Tg} \mathrm{C} \mathrm{yr}^{-1}$, using the data of energy consumption and cement production recorded in the "China Statistical Yearbook" (http://www.tjnj.org/diqu/china/ ). Therefore,

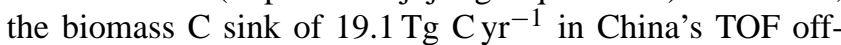
sets $2.1 \%$ of the contemporary fossil $\mathrm{CO}_{2}$ emissions in the country, of which shrubberies and trees on non-forest land offset about 1.1 and $1.0 \%$, respectively. It should be noted that compared with trees in forests, TOF are more easily affected by human beings, and the magnitude of TOF biomass $\mathrm{C}$ sink may vary dramatically with disturbance by humans. 


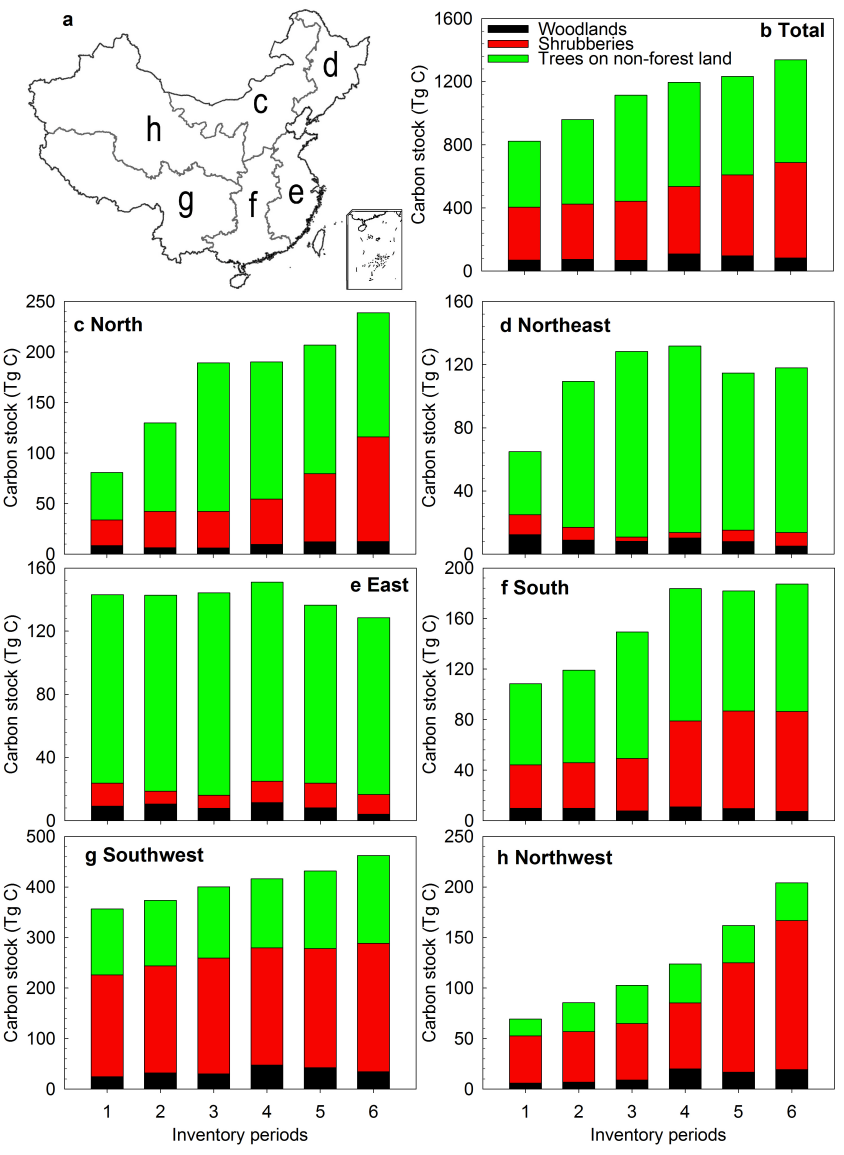

Figure 4. Spatiotemporal distribution of biomass $\mathrm{C}$ stocks among the entire TOF and each group. (a) Regional map; (b) total; (c) northern China (including Beijing, Tianjin, Hebei, Shanxi, and Inner Mongolia); (d) northeastern China (including Liaoning, Jilin, and Heilongjiang); (e) eastern China (including Shanghai, Jiangsu, Zhejiang, Anhui, Fujian, Jiangxi, and Shandong); (f) southern China (including Henan, Hubei, Hunan, Guangdong, Guangxi, and Hainan); (g) southwestern China (including Chongqing, Sichuan, Guizhou, Yunnan, and Tibet); (h) northwestern China (including Shaanxi, Gansu, Qinghai, Ningxia, and Xinjiang). The numbers 1 through 6 represent the inventory periods of 1977-1981, 1984-1988, 1989-1993, 1994-1998, 1999-2003, and 2004-2008, respectively.

\subsection{Regional patterns and dynamics of TOF biomass $\mathrm{C}$ stocks}

Although there were some periodic variations, the total TOF biomass $\mathrm{C}$ stocks in China have been steadily increasing over the last three decades (Fig. 4b). The biomass $\mathrm{C}$ stock in woodlands was small and has remained relatively stable because of limited areas that were suitable for woodlands. Shrubberies and trees on non-forest land had comparable shares in terms of contributing to the total TOF biomass $\mathrm{C}$ stock and sink over the study period al-
Table 3. Comparison of biomass $\mathrm{C}$ stocks and $\mathrm{C}$ sinks between China's forests and China's TOF during 1977-2008. The C estimates of China's forests are based on Guo et al. (2013).

\begin{tabular}{lrrrr}
\hline \multirow{2}{*}{ Period } & \multicolumn{2}{c}{ C stock $(\mathrm{Tg} \mathrm{C})$} & \multicolumn{2}{c}{ C sink $\left(\mathrm{Tg} \mathrm{C} \mathrm{yr}^{-1}\right)$} \\
\cline { 2 - 5 } & TOF & Forests & TOF & Forests \\
\hline $1977-1981$ & 823 & 4972 & - & - \\
$1984-1988$ & 960 & 5178 & 19.6 & 29.5 \\
$1989-1993$ & 1114 & 5731 & 30.9 & 110.6 \\
$1994-1998$ & 1195 & 5781 & 16.1 & 10.1 \\
$1999-2003$ & 1233 & 6293 & 7.7 & 102.3 \\
$2004-2008$ & 1339 & 6868 & 21.1 & 114.9 \\
\hline $1977-2008$ & 516 & 1896 & 19.1 & 70.2 \\
\hline
\end{tabular}

though their contributions to the $\mathrm{C}$ sink were periodically varying (Fig. 4b; Table 2).

Unlike forested land and forest $\mathrm{C}$ stocks in China, which strongly echo forest management programs and policies by the central government, the regional patterns and dynamics of $\mathrm{C}$ stocks in TOF more likely illustrate complex interactions among regional climate, energy use, and socioeconomic influences during China's rapid economic growth. For instance, in the dry northwest region, where there are fewer trees, shrubberies dominate the biomass $\mathrm{C}$ stocks of TOF (Fig. 4h). There was a remarkable increase in shrubberies' biomass $\mathrm{C}$ stocks over the decades, probably reflecting a switch of energy use by local people from a reliance on fuelwood to more efficient coal or natural gas. The southwest region of China covers the Tibetan highlands, and shrubberies are also the dominant natural vegetation. However, because nomadic people in the plateau have kept their traditional way of life and use animal wastes as fuels, there were no particular changes in biomass $\mathrm{C}$ stocks of each TOF group besides slow increases (Fig. 4g). China's interior regions from the northern plateau to the southern mountains (Fig. 4c, f) have climates that can support more trees, and as in the northwest region, local people also heavily relied on fuelwood a few decades ago. These regions now have significant increases of biomass $\mathrm{C}$ stocks in both trees on non-forest land and shrubberies (Fig. 4c, f). Ye and She (2010) also indicated that shrubberies in Guangdong province, in southern China, have functioned as C sinks with $2.5 \mathrm{Tg}$ C from 1988-2007 due to the accumulated increase in shrubbery biomass $\mathrm{C}$ stocks from 3.9 Tg C in 1988 to $6.4 \mathrm{Tg} \mathrm{C}$ in 2007.

In contrast, climate in both eastern and northeastern China favors the growth of trees (Fig. 4d, e). The east, both historically and in modern times, is the most affluent and economically advanced region in China, and the $\mathrm{C}$ stock in trees on non-forest land has been quite consistent and dominant (Fig. 4e). Liu (2010) also found that biomass C stocks in trees on non-forest land were a major component of biomass $\mathrm{C}$ stocks of the total TOF in Jiangsu province (eastern China). In the northeastern region, the biomass $\mathrm{C}$ stock in trees on 
non-forest land was low in the 1970s and increased abruptly in the 1980s and 1990s (Fig. 4d). However both eastern and northeastern regions experienced some declines in biomass $\mathrm{C}$ stocks in trees on non-forest land in the last decade, which can likely be attributed to the increased pressure of urban development.

The diverse regional patterns and dynamics of TOF $\mathrm{C}$ stocks reveal complex interactive relationships between people, natural resources and economic development, and their feedbacks on the $\mathrm{C}$ dynamics of TOF. It is inevitable that in a country like China, with a high population density and limited arable land, many natural forests have given a way to other land uses. Because TOF are likely less demanding in terms of land and maintenance and more integral to peoples' daily lives, promotion of TOF in a highly populated country may provide social, economic, and environmental synergies for achieving both $\mathrm{C}$ benefits and many other ecosystem services.

\subsection{Error of estimations}

Similar to the estimation of national forest biomass $\mathrm{C}$ stocks derived from inventory data, for TOF's biomass $\mathrm{C}$ estimation, the most important errors may also come from forest inventory data and the estimation of regional biomass stocks by applying regression models (e.g., Eqs. 3 and 4 in this study). Phillips et al. (2000) studied the errors in estimates of forest timber volumes and their changes in five southeastern states in the United States and found that among three major error sources (sampling error, measurement error, and regression error), it was mainly the sampling error that was responsible for the total error in forest timber volumes and their changes, accounting for 90-99\% of total variance. Forest inventory data used in our study specified the precision requirement in sampling design: the area and volume precision were required to be $>90 \%$ in most provinces (but $>85 \%$ for Beijing, Shanghai, and Tianjin) (Guo et al., 2013). In addition, for woodlands, we found that about $87 \%$ (151 of 173) of the predicted data was within the range of our regression model; for trees on non-forest land, this proportion was up to $99 \%$ (336 of 340). Combined with their high $R$ square values, biomass estimates for woodlands and trees on non-forest land are of relatively high precision.

For shrubberies, the major error may be generated from the use of the mean biomass density. In general, the method could result in some overestimation of biomass $\mathrm{C}$ stocks of shrubberies because collected data were usually from shrub stands with better growing conditions (Guo et al., 2010).

\section{Conclusions}

Assessing TOF poses different challenges than assessing forests, especially for the variability and heterogeneity of TOF systems, because of their sparse distributions and com- plex ownerships and institutional arrangements (de Foresta et al., 2013). Despite measurable progress, hard data on TOF across large areas (regional and national levels) remains scarce (de Foresta et al., 2013). In this study, based on six periods of forest inventory data, we made the first nationalscale TOF assessment for China, and concluded that the total TOF biomass $\mathrm{C}$ stock increased to $1339 \mathrm{Tg} \mathrm{C}$ from an initial stock of $823 \mathrm{Tg} \mathrm{C}$ and that China's TOF have accumulated C of $516 \mathrm{Tg}$ between 1977 and 2008, with an average $\mathrm{C}$ sink of $19.1 \mathrm{Tg} \mathrm{C} \mathrm{yr}^{-1}$. These estimates equaled $16.5-20.7 \%$ of the contemporary biomass $\mathrm{C}$ stock in the country's forests and $27.2 \%$ of the total forest biomass C sink between 1977 and 2008. Furthermore, the biomass $\mathrm{C}$ sink in China's TOF offsets $2.1 \%$ of the contemporary fossil $\mathrm{CO}_{2}$ emissions in the country. This study highlights the importance of TOF in estimating regional and global terrestrial $\mathrm{C}$ budget, given the magnitude of contributions that they can make to $\mathrm{C}$ stocks and sinks in China. TOF in countries with high populations or dry environments with low forest coverage may have a particular role in social, economic, and environmental synergies because of their multi-beneficial functions for ecosystem services, including the service of $\mathrm{C}$ sequestration that helps mitigate global climate change. Understanding diverse regional dynamics of TOF is important not only for predicting their impact on the national $\mathrm{C}$ budget, but also for evaluating other ecosystem services they may provide to humanity.

\section{The Supplement related to this article is available online at doi:10.5194/bg-11-4115-2014-supplement.}

Acknowledgements. This work was supported by the $\mathrm{Na}$ tional Basic Research Program of China on Global Change (2010CB950600), National Natural Science Foundation of China (31321061 and 31330012), "Strategic Priority Research Program - Climate Change: Carbon Budget and Related Issues" of the Chinese Academy of Sciences (XDA05050300), and the State Forestry Administration of China (2013-R13).

Edited by: F. Carswell

\section{References}

Bellefontaine, R., Petit, S., Pain-Orcet, M., Deleporte, P., and Bertault, J. G.: Trees Outside Forests. FAO Conservation Guide no. 35, Rome, Italy, 2002.

Chinese Ministry of Forestry: Forest Resource Statistics of China (1977-1981). Department of Forest Resource and Management, Chinese Ministry of Forestry, Beijing, China, 1983.

Chinese Ministry of Forestry: Forest Resource Statistics of China (1984-1988). Department of Forest Resource and Management, Chinese Ministry of Forestry, Beijing, China, 1989.

Chinese Ministry of Forestry: Forest Resource Statistics of China (1989-1993). Department of Forest Resource and Management, Chinese Ministry of Forestry, Beijing, China, 1994. 
Chinese Ministry of Forestry: Forest Resource Statistics of China (1994-1998). Department of Forest Resource and Management, Chinese Ministry of Forestry, Beijing, China, 2000.

Chinese Ministry of Forestry: Forest Resource Statistics of China (1999-2003). Department of Forest Resource and Management, Chinese Ministry of Forestry, Beijing, China, 2005.

Chinese Ministry of Forestry: Forest Resource Report of China the 7th national forest resources inventory. China Forestry Publishing House, Beijing, China, 2010.

de Foresta, H., Somarriba, E., Temu, A., Boulanger, D., Feuilly, H., and Gauthier, M.: Towards the Assessment of Trees Outside Forests. FAO Resources Assessment Working Paper no. 183, Rome, Italy, 2013.

Dolman, A. J., Shvidenko, A., Schepaschenko, D., Ciais, P., Tchebakova, N., Chen, T., van der Molen, M. K., Belelli Marchesini, L., Maximov, T. C., Maksyutov, S., and Schulze, E.-D.: An estimate of the terrestrial carbon budget of Russia using inventory-based, eddy covariance and inversion methods, Biogeosciences, 9, 5323-5340, doi:10.5194/bg-9-5323-2012, 2012.

Fang, J. Y. and Chen, A. P.: Dynamic forest biomass carbon pools in China and their significance, Acta Botan. Sin., 43, 967-973, 2001.

Fang, J. Y., Wang, G. G., Liu, G. H., and Xu, S. L.: Forest biomass of China: an estimation based on the biomass-volume relationship. Ecol. Appl., 8, 1084-1091, 1998.

Fang, J. Y., Chen, A. P., Peng, C. H., Zhao, S. Q., and Ci, L. J.: Changes in forest biomass carbon storage in China between 1949 and 1998, Science, 292, 2320-2322, 2001.

Fang, J. Y., Guo, Z. D., Piao, S. L., and Chen, A. P.: Terrestrial vegetation carbon sinks in China, 1981-2000. Sci. China Ser. D, 50, 1341-1350, 2007.

Fang, J. Y., Guo, Z. D., Hu, H. F., Kato, T., Muraoka, H., and Son, Y. : Forest biomass carbon sinks in East Asia, with special reference to the relative contributions of forest expansion and forest growth, Glob. Change Biol., 20, 2019-2030, 2014.

FAO: Trees Outside Forests: Towards Rural and Urban Integrated Resources Management: Contribution to the Forest Resources Assessment 2000 Report. FAO working paper, Rome, Italy, 2001.

Guo, Z. D.: Biomass carbon stocks and ecosystem carbon budget in China's forests, Ph. D., Peking University, Beijing, China, 2011.

Guo, Z. D., Fang, J. Y., Pan, Y. D., and Birdsey, R.: Inventory-based estimates of forest biomass carbon stocks in China: A comparison of three methods, For. Ecol. Manage., 259, 1225-1231, 2010.

Guo, Z. D., Hu, H. F., Li, P., Li, N. Y., and Fang, J. Y.: Spatiotemporal changes in biomass carbon sinks in China's forests from 1977 to 2008, Sci. China Life Sci., 56, 661- 671, 2013.

Hu, H. F., Wang, Z. H., Liu, G. H., and Fu, B. J.: Vegetation carbon storage of major shrublands in China, Chin. J. Plant Ecol., 30, 539-544, 2006.
IPCC: Climate Change 2007: The Physical Science Basis, in: Contribution of Working Group I to the Fourth Assessment Report of the Intergovernmental Panel on Climate Change, edited by: Solomon, S., Qin, D., Manning, M., Chen, Z., Marquis, M., Averyt, K. B., Tignor, M., and Miller, H. L., Cambridge University Press, Cambridge, UK and New York, USA, 2007.

Krishnankutty, C. N., Thampi, K. B., and Chundamannil, M.: Trees Outside Forests (TOF): A Case Study of the Wood ProductionConsumption Situation in Kerala, Int. Forest. Rev., 10, 156-164, 2008.

Li, H. K., Lei, Y. C., and Zeng, W. S.: Forest carbon storage in China estimated using forestry inventory data, Sci. Silv. Sin., 47, 7-12, 2011.

Liu, L.: Study on forest biomass and productivity based on continuous forest resources inventory and remote sensing information, Master, Nanjing Forestry University, Nanjing, China, 2010.

Long, A. J. and Nair, P. K. R.: Trees outside forests: agro-, community, and urban forestry, New Forests, 17, 145-174, 1999.

Nair, P. K. R.: Agroforestry systems and snvironmental quality: introduction, J. Environ. Qual., 40, 784-790, 2011.

Nowak, D. J. and Crane, D. E.: Carbon storage and sequestration by urban trees in the USA, Environ. Poll., 116, 381-389, 2002.

Pan, Y. D., Luo, T. X., Birdsey, R., Hom, J., and Melillo, J.: New estimates of carbon storage and sequestration in China's forests: effects of age-class and method on inventory-based carbon estimation, Clim. Change, 67, 211-236, 2004.

Pan, Y. D., Birdsey, R. A., Fang, J. Y., Houghton, R., Kauppi, P. E., Kurz, W. A., Phillips, O. L., Shvidenko, A., Lewis, S. L., Canadell, J. G., Ciais, P., Jackson, R. B., Pacala, S. W., McGuire, A. D., Piao, S. L., Rautiainen, A. Sitch, S., and Hayes, D.: A large and persistent carbon sink in the world's forests, Science, 333, 988-993, 2011.

Phillips, D. L., Brown, S. L., Schroeder, P. E., and Birdsey, R. A.: Towards error analysis of large-scale forest carbon budgets, Global Ecol. Biogeogr., 9, 305-313, 2000.

Teobaldelli, M., Somogyi, Z., Migliavacca, M., and Usoltsev, V. A.: Generalized functions of biomass expansion factors for conifers and broadleaved by stand age, growing stock and site index, For. Ecol. Manage., 257, 1004-1013, 2009.

Ye, J. S. and She, G. H.: Forest carbon dynamics in Guangdong province. J. Nanjing Forest. U. (Nat. Sci. Edit), 34, 7-12, 2010.

Zhang, C. H, Ju, W. M., Chen, J. M., Zan, M., Li, D. Q., Zhou, Y. L., and Wang, X. Q.: China's forest biomass carbon sink based on seven inventories from 1973-2008, Clim. Change, 118, 933948, 2013.

Zomer, R. J., Trabucco, A., Coe, R., and Place, F.: Trees on Farm: Analysis of Global Extent and Geographical Patterns of Agroforestry, ICRAF Working Paper no. 89, World Agroforestry Centre, Nairobi, Kenya, 2009. 